\title{
Alcohol-dependent patients receiving specialised outpatient care: an overview of gender issues
}

Dependentes do álcool atendidos em ambulatório especializado: um olhar na questão do gênero

Márcia Fonsi Elbreder', Rebeca de Souza e Silva', Ronaldo Laranjeira'

\begin{abstract}
Objective: The objective of the present study, with focus on gender, was aimed at evaluating alcohol-dependent individual in terms of socio-demographic variables related to alcohol consumption and therapeutic interventions. Methods: This is a retrospective cross-sectional study of 1,051 patients (833 men and 218 women), with diagnosis of alcohol dependence syndrome, according to ICD-10 criteria, who had sought treatment for the first time at a specialised health centre between 2000 and 2006. Results: The results showed that women, compared to men, are more likely to be unemployed and without partner, in addition to having higher educational level, latter age of alcohol initiation, needing less outpatient alcohol detoxification program, consuming more fermented beverage, presenting less psychiatric comorbidities, and using less coadjutant medications during treatment. Conclusion: We can state that some peculiarities exist permeating both gender and alcohol consumption. A further focus on the characteristics of each population is needed to facilitate the adequate use of therapeutic interventions according to gender specificities.
\end{abstract}

\section{RESUMO}

Objetivo: $O$ objetivo do presente estudo, com foco no gênero, foi avaliar dependentes de álcool em termos de variáveis sociodemográficas, relacionadas ao consumo de álcool e intervenções terapêuticas. Métodos: Este é um estudo retrospectivo transversal com 1.051 pacientes (833 homens e 218 mulheres), com diagnóstico de síndrome de dependência do álcool, de acordo com o CID-10, que procuraram tratamento pela primeira vez em um serviço especializado, entre 2000 e 2006. Resultados: Os resultados mostraram que as mulheres, comparadas aos homens, eram desempregadas e sem companheiro, além de ter melhor nível educacional, iniciarem o consumo alcoólico mais tardiamente, necessitarem menos do programa de desintoxicação alcoólica ambulatorial, consumirem mais bebidas fermentadas, apresentarem menos comorbidades psiquiátricas e usarem menos medicamentos coadjuvantes durante o tratamento. Conclusão: Pode-se afirmar que existem algumas peculiaridades que permeiam ambos os gêneros e o consumo alcoólico. É necessário ampliar o foco nas características de cada população, a fim de facilitar intervenções terapêuticas mais ajustadas, de acordo com as especificidades.

1 Universidade Federal de São Paulo (Unifesp). 


\section{INTRODUCTION}

Gender differences in alcohol use have been important ways in which societies have symbolized and regulated gender roles. There is evidence that the consumption of alcoholic beverages by women was a practice condemned within the ancient societies, whose punishment was more rigorous with them than with men!.

The practical result of this intense social stigma and embarrassment applied to alcoholic women kept them in hiding ${ }^{1}$ and until the early 1990s the substance abuse treatment literature was based primarily on male samples, or mixed samples of men and women without any interesting on gender differences and, as a result, women remained subestimated and sub-represented in the research².

Over the last decade researchers began to focus on the disparities between men and women and point out there are a number of target characteristics (socio-demographic, biological, clinical, cultural) can be seen as an important key to answering broader questions about gender-specific predictors of treatment outcomes ${ }^{3}$.

Due to the importance of this theme and scantiness of studies on this issue the objective of the present study was to evaluate the alcohol-dependent individual in terms of socio-demographic variables related to alcohol consumption and therapeutic interventions, on focus in the gender.

\section{METHODS}

This is a cross-sectional study involving 1,051 alcoholic patients (833 men and 218 women), according to ICD-10 criteria, who had sought treatment for the first time at the Alcohol and Drugs Research Unit (Uniad), a service linked to the Federal University of São Paulo, between 2000 and 2006.

Outpatient screening for alcoholism was conducted by psychologists, physicians, and nurses in order to collect sociodemographic data, investigate patterns and frequency of alcohol consumption, evaluate previous and current therapeutic interventions, make differential diagnosis between alcohol abuse and alcoholism (according to ICD-10 criteria), elucidate physical, psychological, and social problems resulting from alcohol use, observe physical signs and symptoms of alcohol withdrawal syndrome (AWS), and finally, verify the need for alcoholic detoxification (DST) with specific medications.

The Short Alcohol Dependence Data Questionnaire (SADD) was used to evaluate the severity of dependence syndrome in those cases of diagnosed alcoholism. This instrument was validated for use in Brazil by Jorge and Masur $(1985)^{4}$ and has been regularly applied to the patients attending this unit. It consists of 15 items with scores ranging from 0 to $3(0=$ never, $1=$ a few times, $2=$ many times, $3=$ always) in which the following classification can be achieved: mild dependence (1 to 9 points), moderate (10 to 19 ), and severe (20 to 45).
Chi-square test was used to analyse the variables and Student-t test to compare the mean values between both groups, considering $p<0.05$ for statistical association.

This study was approved by the Ethics Committee of the Federal University of São Paulo (Process number 1627/05).

\section{RESULTS}

Table 1 shows the distribution of socio-demographic data regarding the sample studied. With regard to marital status, we have found statistical association and also a greater proportion of women living alone.

The educational level among women was at the extremes, that is, illiterates and university graduates. Also, it was observed a great proportion of unemployed women.

Table 2 lists the distribution of alcohol consumptionrelated variables in the sample, with women using more fermented beverages.

Alcohol dependence was found to be severe in both groups, although no statistical association was observed.

Table 3 shows the distribution of treatment-related variables in the sample, with women using less coadjutant medications than men. Also, fewer women were found to have some form of psychiatric disorder and used less outpatient alcohol detoxification program.

Table 1. Gender distribution of socio-demographic variables in the sample

\begin{tabular}{|c|c|c|c|c|c|}
\hline & \multicolumn{4}{|c|}{ Gender } & \multirow{3}{*}{$\chi^{2}$} \\
\hline & \multicolumn{2}{|c|}{ Men } & \multicolumn{2}{|c|}{ Women } & \\
\hline & N & $\%$ & N & $\%$ & \\
\hline \multicolumn{6}{|l|}{ Marital status $(\mathrm{N}=1,051)$} \\
\hline No partner & 411 & 49.4 & 137 & 62.8 & \multirow{3}{*}{$0.001^{*}$} \\
\hline With partner & 422 & 50.6 & 81 & 37.2 & \\
\hline Total & 833 & 79.3 & 218 & 20.7 & \\
\hline \multicolumn{6}{|l|}{ Educational level $(\mathrm{N}=1,051)$} \\
\hline Illiterate & 32 & 4.0 & 16 & 7.3 & \multirow{8}{*}{$0.001^{*}$} \\
\hline Elementary school (i) & 337 & 40.4 & 83 & 38.2 & \\
\hline Elementary school (c) & 81 & 10.0 & 13 & 6.0 & \\
\hline High school (i) & 77 & 8.5 & 15 & 6.9 & \\
\hline High school (c) & 160 & 19.2 & 30 & 13.8 & \\
\hline University graduate (i) & 75 & 9.0 & 20 & 9.2 & \\
\hline University graduate (c) & 71 & 8.5 & 41 & 19.0 & \\
\hline Total & 833 & 79.3 & 218 & 20.7 & \\
\hline \multicolumn{6}{|c|}{ Occupational situation $(\mathrm{N}=1,051)$} \\
\hline Unemployed & 348 & 72.0 & 136 & 28.0 & \multirow{3}{*}{$.000^{*}$} \\
\hline Employed & 485 & 85.5 & 82 & 14.5 & \\
\hline Total & 833 & 79.3 & 218 & 20.7 & \\
\hline
\end{tabular}

i: incomplete; c: complete. 
Table 2. Gender distribution of alcohol consumption-related variables in the sample

\begin{tabular}{|c|c|c|c|c|c|}
\hline & \multicolumn{4}{|c|}{ Gender } & \multirow{3}{*}{$\chi^{2}$} \\
\hline & \multicolumn{2}{|c|}{ Men } & \multicolumn{2}{|c|}{ Women } & \\
\hline & N & $\%$ & $\mathbf{N}$ & $\%$ & \\
\hline \multicolumn{6}{|c|}{ Type of beverage used $(\mathrm{N}=1,049)$} \\
\hline Distilled & 466 & 82.3 & 100 & 17.7 & \multirow{4}{*}{$.000^{*}$} \\
\hline Fermented & 123 & 64.1 & 69 & 31.9 & \\
\hline Distilled + fermented & 242 & 83.2 & 49 & 16.8 & \\
\hline Total & 831 & 79.2 & 218 & 20.8 & \\
\hline \multicolumn{6}{|c|}{$\begin{array}{l}\text { Frequency of alcohol consumption in the } \\
\text { last month }(N=1,048)\end{array}$} \\
\hline Daily use & 330 & 79.9 & 83 & 20.1 & \multirow{9}{*}{$0.488^{*}$} \\
\hline 5-6 times a week & 163 & 76.5 & 50 & 23.5 & \\
\hline 3-4 times a week & 123 & 77.4 & 36 & 22.6 & \\
\hline $1-2$ times a week & 66 & 81.5 & 15 & 18.5 & \\
\hline $2-3$ times a month & 14 & 70.0 & 6 & 30.0 & \\
\hline Once a month & 7 & 100.0 & 0 & .0 & \\
\hline$<1$ time a month & 1 & 50.0 & 1 & 50.0 & \\
\hline Did not drink & 126 & 82.4 & 27 & 17.6 & \\
\hline Total & 830 & 79.2 & 218 & 20.8 & \\
\hline \multicolumn{6}{|l|}{$\operatorname{SADD}(N=1,029)$} \\
\hline Mild & 33 & 75.0 & 11 & 25.0 & \multirow{4}{*}{0.283} \\
\hline Moderate & 211 & 82.4 & 45 & 17.6 & \\
\hline Severe & 570 & 78.2 & 159 & 21.8 & \\
\hline Total & 814 & 79.1 & 215 & 20.9 & \\
\hline
\end{tabular}

\section{DISCUSSION}

The present study shows the high proportion of women living alone as well as scientific evidence suggesting that marriage is a protective factor for men. On the other hand, marriage contributes for a shorter time to relapse among women and indicates that women using alcohol, compared to men, are more likely to marry partners who consume alcoholic beverage heavily ${ }^{5,6}$.

In Brazil, the rate of illiteracy for men and women aged 15 years old and above was estimated to be $11.3 \%$ and $10.8 \%$, respectively ${ }^{7}$ and the average of the study in Brazil is 7.4 years $^{8}$. Although ethnicity wasn't addressed in this study, the rate of illiteracy and functional illiteracy among the black and mulatto population is about twice higher than that of white population. In turn, the proportion of white individuals aged 25 years old or more with at least 15 years of education is three times higher than that of black and mulatto ${ }^{7}$. The specialised literature points that women using psychoactive substances have lower educational level compared to men'10.

The findings from this study not only indicate a great number of male and female patients with low educational level (incomplete elementary school), but also a greater proportion of illiterate women compared to men. On the other hand, more women have superior education compared to
Table 3. Gender distribution of treatment-related variables in the sample



men, a fact that corroborates the findings reported by Zilberman et al. ${ }^{11}$.

The low educational level might lead to an unfavourable occupational situation, and the literature shows that women are less likely to be employed than men ${ }^{12}$, maybe because the former functions in certain societies, namely: wife, housekeeper, and mother.

The beginning age of regular consumption of alcoholic beverage was 19 years $(S D=6.7)$ for men and 24 years (SD $=11.9)$ for women, whereas the mean age of the patients was 42 years $(S D=10.6$ and $S D=11.3$, respectively for men and women). The telescopic effect, in which women begin drinking later than men but exhibit earlier negative consequences, is cited several times in the literature ${ }^{13,14}$.

In this study, distilled beverages were widely consumed by both men and women, and cachaça was the first option because its low cost. Laranjeira and Hinkly ${ }^{15}$ analysed the density of alcoholic beverages selling points in low socioeconomic regions of São Paulo City and they observed 29 outlets per km or one outlet for every 12 owners. They concluded that this was the highest outlet density described in the medical literature, with $72 \%$ of the owners indicating cachaça as the most widely sold beverage. 
Despite women are more vulnerable to adverse effects of alcohol $^{16}$, it is necessary to get additional information (last alcohol consumption, the level of dependence, type of beverage used, years of alcohol consumption) in order to increase understanding about the fewer needing care the outpatient alcohol detoxification program.

The literature ensures that depressive and anxiety disorders are among the most commonly psychiatric comorbidities found in alcoholic women, with rates higher than those for alcoholic men ${ }^{17,18}$, who in turn have more anti-social disorders $^{19}$. The findings of this study, however, show a high proportion of men presenting depressive and anxiety disorders. As it is not uncommon to find a high rate of dropout during the first months of treatment, a great number of patients do not receive any psychiatric evaluation, thus reinforcing the idea that the rates of psychiatric disorders would be higher than those found elsewhere.

Stigma and social sanctions interfere with the early identification of alcoholism as women are less likely to seek specialised treatment compared to men ${ }^{20}$. Moreover, not only there is a lack of practitioners in other areas who are able to identify the real cause for help seeking and the problems involved ${ }^{21}$, but also the health mental professionals have difficulty in treating such patients ${ }^{22}$.

In Brazil, patients have opted for disulfiram as coadjutant medication because of its low price. In addition, there is a great concentration of severely alcoholic patients and a rapid-acting medication is of great value provided that the patient understands the treatment goal, becomes motivated to keep abstinence, and has responsibility on the medication being taken. A recent study has proved that despite being an old drug, disulfiram is effective in keeping alcoholic individuals under outpatient treatment regardless of their gender ${ }^{23}$.

\section{CONCLUSION}

The identification of structural characteristics of treatment populations is important to the alcohol treatment field and would be of great importance to maximize the probability of successful outcome.

\section{DISCLOSURE STATEMENT}

All contributed authors declare that there are no conflicts of interest and that no funding source has been provided. Further on all authors have approved the final article.

\section{ACKNOWLEDGEMENTS}

The authors like to thank Christof Elbreder and José Tadeu Sales for helping prepare this manuscript.

\section{REFERENCES}

1. Blume S, Zilberman ML. Women: clinical aspects. In: Lowison J, Ruiz P, Millman Langrod JG, editors. Substance abuse: a comprehensive textbook. Lippincott Willians \& Wilkins; 2004, p. 1049-64.

2. Greenfield SF, Brooks AJ, Gordon SM, Kropp F, Mc Hugh RK, Lincoln M, et al. Substance abuse treatment entry, retention and outcome in women: a review of the literature. Drug Alcohol Depend. 2007;86(1):1-21.

3. Holmila M, Raitasalo K. Gender differences in drinking: why do they still exist? Addiction. 2005;100(12):1763-9.

4. Jorge M, Masur J. The use of the short-form alcohol dependence data questionnaire (SADD) in Brasilian alcoholic patients. Br J Addict. 1985;80(3):301-5.

5. Schneider KM, Kviz J, Isola ML, Filstead WJ. Evaluating multiple outcomes and gender differences in alcoholism treatment. Addict Behav. 1995;20(1):1-21.

6. Walitzer KS, Dearing RL. Gender differences in alcohol and substance use relapse. Clin Psychol Rev. 2006;26(2):128-48

7. Comissão Nacional sobre Determinantes Sociais da Saúde. Disponível em: http://portalsaude.gov.br/portal/arquivos/pdf/determinantesdesauderelatorio.pdf. Acessado em: 23 fev. 2010

8. IBGE. Instituto Nacional de Geografia e Estatística. Disponível em: http://ibge.gov.br/ home/presidencia/noticias/noticia_visualiza.php?id_noticia=1455\&id_pagina=1. Acessado em: 22 fev. 2010.

9. Wechsberg WM, Craddock SG, Hubbard RL. How are women who enter substance abuse treatment different than men? A gender comparison from the Drug Abuse Treatment Outcome Study (DATOS). Drugs Soc. 1998;13(1/2):97-115.

10. Arfken CL, Di Menza S, Klein C, Schuster CR. Gender differences in problem severity at assessment and treatment retention. J Subst Abuse Treat. 2001;20(1):53-7.

11. Zilberman ML, Hochgraf PB. Drug-dependent women: demographic and clinical characteristics in Brasilian sample. Subst Use Misuse. 2001;36(8):1111-27.

12. Green CA, Polen MR, Dickinson DM, Lynch FL, Bennett MD. Gender differences in predictors of initiation, retention, and completion in an HMO-based substance abuse treatment program. J Subst Abuse Treat. 2002;23(4):285-95.

13. Johnson P, Richter L, Herbert KD, McLellan AT, Carise DA. Telescoping of drinking-related behaviors: gender, racial/ethnic and age comparisions. Subst Use Misuse. 2005;40(8):1139-51.

14. Diehl A, Croissant B, Batra A, Mundle G, Nakovics H, Mann K. Alcoholism in women: is it different in onset and outcome compared to men? Eur Arch Psychiatry Clin Neurosci. 2007;257(6):344-51.

15. Laranjeira R, Hinkly D. Evaluation of alcohol outlet density and its relation with violence. Rev Saude Publica. 2002;36(4):455-61.

16. Graham K, Wilsnack R, Dawson D, Vogeltanz. Should alcohol consumption measures be adjusted for gender differences? Addiction. 1998;93(8):1137-47.

17. Weinberger AH, Maciejewski, McKee SA, Reutenauer EL, Mazure CM. Gender differences in associations between lifetime alcohol, depression, panic disorder, and posttraumatic stress disorder and tobacco withdrawal. Am J Addict. 2009;18(2):140-7.

18. Ameida-Filho N, Lessa I, Magalhães L, Araúho MJ, Aquino E, de Jesus MJ. Co-occurrence patterns of anxiety, depression and alcohol use disorders. Eur Arch Psychiatry Clin Neurosci. 2007;257(7):423-31.

19. Brown JM, Nixon SJ. Gender and drug differences in antisocial personality disorder. J Clin Psychol. 1997;53(4):301-5.

20. Belló M, Puentes-Rosas E, Medina-Mora Icaza ME. The role of gender in the demand for treatment of problems associated with alcohol consumption in Mexico. Rev Panam Salud Publica. 2008;23(4):231-6.

21. Hearne R, Connolly A, Sheehan J. Alcohol abuse: prevalence and detection in a general hospital. J R Soc Med. 2002;95(2):84-7.

22. Pillon SC, Laranjeira R. Formal education and nurses' attitudes towards alcohol and alcoholism in a Brazilian sample. Sao Paulo Med J. 2005;123(4):175-80.

23. Elbreder MF, De Humerez DC, Laranjeira R. The use of disulfiram for alcohol-dependent patients and duration of outpatient treatment. Eur Arch Psychiatry Clin Neurosci. 2009. [Epub ahead of print] 